http://dx.doi.org/10.12775/szhf.2021.014

\author{
MaKs Sipowicz \\ Monash University, Melbourne, Australia \\ E-MAIL: MAKS.SIPOWICZ@GMAIL.COM \\ ORCID: 0000-0001-9618-5924
}

\title{
Mary Astell on the Social Nature of the Cartesian Passions ${ }^{*}$
}

\begin{abstract}
Scholars have long recognised that Mary Astell builds her feminist critique of society on a foundation of Cartesian views about human nature and the passions. At the same time, the full extent of the influence of Descartes' view of embodiment on the solution Astell proposes in her Serious Proposal to the Ladies is only beginning to come to light. In this paper, I contribute to this ongoing project by arguing that Astell builds on Descartes' ideas by addressing a blind spot in his view, namely, that that the embodied self is socially situated, and that therefore, our social context plays a crucial formative role in the development of our passions. In doing so, I show Astell extends Cartesian philosophy beyond an egalitarian feminist critique of society, but also to a positive political theory offering a solution to the problems she identifies. Thusly, Astell shows the political potential of Cartesian philosophy as a framework for social critique and to seek solutions to the problems such a critique can bring out.
\end{abstract}

Keywords: Mary Astell, Embodiment, Passions

This research was supported with funding from the Australian Government under the Research Training Scheme. I'm grateful to Jacqueline Broad for her feedback and support in developing this paper. 
In the first part of her Serious Proposal to the Ladies (1694), Mary Astell argues that custom and prejudice are the reasons not only behind women's disadvantage in society but also of their vice. ${ }^{1}$ Astell builds her feminist critique on the basis of Cartesian views about human nature and the passions. In its most basic form, her argument is that the mind is not gendered, and therefore, it is not an innate lack of capacities but rather prejudice which leads to women's position. The arguments she gives in her two Proposals are important not only for the feminist agenda they promote but also as an example of how a social theory can be built on a foundation of Cartesian philosophy. Descartes himself avoided any significant discussion of the social and political aspects of his views, with the exception of the "Letter to the Sorbonne" that he appended as an introduction to his Meditations, which served to argue that his arguments were not threatening to the scholastic status quo. ${ }^{2}$

Astell's feminist critique in the Proposals encompasses a number of interrelated arguments. Broadly, the foundation is an account of human nature that reaches two conclusions, first, that the mind is not gendered, and second, that the embodied self is. The distinction between the immaterial mind and the embodied self is crucial to establishing the social causes of women's position in society. If the mind is not gendered, then at the level of ontology, there is no distinction between the thinking parts of men and women. The

1 Throughout this paper, I will cite Astell's works by the following abbreviations: SP I Serious Proposal, part I, SP II - Serious Proposal, part II, CR - The Christian Religion, as Professed by a Daughter of the Church of England. I will cite Descartes' work by referring to the volume and page number of the Adam and Tannery edition (AT), followed by a reference to the English edition edited by Cottingham, Stoothoff and Murdoch given as CSM, followed by the volume and page numbers. I cite Descartes' correspondence with Princess Elisabeth with the abbreviation " $\mathrm{C}$ " followed by the page number, referring to the edition by Shapiro. I take all of the quotations in English from the CSM edition, with the exception of the correspondence with Elisabeth, which is taken from Shapiro. References to the editions used are included in the bibliography.

2 We can also consider that Descartes admitted in his conversation with Frans Burman that he "does not like writing on ethics" (C 352, AT V 178). This suggests that at least as far as his philosophy is concerned, Descartes' interests end with matters of science and metaphysics and not the social implications of these views. Some scholars have attempted to understand what Descartes' political views might be, see, for instance: Richard A. Watson, Descartes's Ballet: His Doctrine of the Will and His Political Philosophy (South Bend: St. Augustine's Press, 2007); Antonio Negri, Political Descartes: Reason, Ideology and the Bourgeois Project, transl. Alberto Toscano, Matteo Mandarini (London: Verso, 2007). 
embodied self - that is, the self that operates in the external world via its connection to a body (i.e. the embodied aspect of the "embodied self") and has contact with other human beings - is gendered, which then explains the difference in the way men and women are treated. From this, Astell is able to explain the symptoms of this difference, particularly the condition women are in qua members of society, as a result of the way in which their embodied selves are socialised. Astell illustrates this differential conduct towards women most clearly in her analysis of the kinds of passion women cultivate and experience. To this end, Astell adopts key aspects of the Cartesian theory of the passions, expanding it by showing the social causes of the gendered differences in the passions experienced by men and women. Finally, Astell draws on one of Descartes' own methods for moderating the passions - the method of judgment - to show that women already have the capacities required for moderating the passions, and thus striving for virtue. This forms the foundation of her call for a women's educational refuge.

In this paper, I argue that by building on Descartes' philosophy in the way that she does, Astell extends Cartesian philosophy, and in particular the Cartesian theory of the passions, into a social theory. That is to say, Astell uses Cartesian philosophy to give a theory of the social nature of human embodiment and the effect our social context has on shaping the self. Astell brings out and addresses a significant shortcoming in Descartes' view of the embodied self - his failure to see that it is gendered and becomes so as a result of social influences. In extending these ideas not only to a critique of society but also to a proposal for a solution, Astell shows the political value of Cartesian philosophy as a theoretical backdrop to an egalitarian social theory. ${ }^{3}$

3 Astell is not the only early modern philosopher to develop a political theory based in Cartesian philosophy. A similar project was developed by François Poulain de la Barre. For his Cartesian feminist treatises, see Three Cartesian Feminist Treatises, ed. Marcelle Maistre Welch (Chicago: The University of Chicago Press, 2002) and for an excellent overview of his ideas see Siep Stuurman, François Poulain de la Barre and the Invention of Modern Equality (Cambridge: Harvard University Press, 2004). 


\section{Astell's View of Human Nature}

In the Proposals, Astell highlights that what holds women back in society is not an innate lack of ability but rather their lack of access to education, usually caused by custom and societal prejudice. In presenting this argument, Astell relies on the Cartesian view of the immaterial (and therefore, genderless) mind to show that women have the same intellectual capacities as everyone else. ${ }^{4}$ At the same time, Astell acknowledges that the embodied self is gendered - the kinds of option open to us in life, the kinds of opportunity

4 Many feminist scholars suggest that Descartes' view undermines women's position in the world by coding 'rationality' as masculine, see for instance Genevieve Lloyd, The Man of Reason: "Male" and "Female" in Western Philosophy (Minneapolis: University of Minnesota Press, 1984). I do not wish to dispute that the Cartesian view has been used in that way, however, the view which I defend here is that this was not the case for Astell. As, for instance, Jacqueline Broad (Women Philosophers of the Seventeenth Century (Cambridge: Cambridge University Press, 2002)) shows, in the early modern period many women saw Cartesian philosophy as liberating; see also Margaret Atherton, "Cartesian Reason and Gendered Reason", in A Mind of One's Own: Feminist Essays on Reason and Objectivity, eds. Louise M. Antony, Charlotte Witt (Boulder and Oxford: Westview Press, 1993); Ruth Perry, "Radical Doubt and the Liberation of Women", Eighteenth-Century Studies 18, 4 (1985): 472-493; Hilda L. Smith, Reason's Disciples: Seventeenth-Century English Feminists (Chicago: University of Illinois Press, 1982); Hilda L. Smith, "Intellectual Bases for Feminist Analyses: The Seventeenth and Eighteenth Centuries", in Women and Reason, eds. Elizabeth D. Harvey, Kathleen Okruhlik (Ann Arbor: University of Michigan Press, 1992); Katharine M. Rogers, Feminism in EighteenthCentury England (Urbana: University of Illinois Press, 1982). More recently, Karen Detlefsen ("Cartesianism and Its Feminist Promise and Limits: The Case of Mary Astell", in Descartes and Cartesianism: Essays in Honours of Desmond Clarke, eds. Stephen Gaukroger, Catherine Wilson (Oxford: Oxford University Press, 2017)) has shown further that this is the case with Astell specifically. See also, Joan K. Kinnaird, "Mary Astell and the Conservative Contribution to English Feminism”, Journal of British Studies 19, 1 (1976): 61-62; Eileen O’Neill, "Women Cartesians, 'Feminine Philosophy', and Historical Exclusion", in Feminist Interpretations of René Descartes, ed. Susan Bordo (University Park: The Pennsylvania State University Press, 1999); Ruth Perry, "Mary Astell's Response to the Enlightenment", in Women and the Enlightenment, eds. Margaret Hunt, Margaret Jacob, Phyliss Mack, Ruth Perry (New York: Institute for Research in History and the Haworth Press, 1984); Perry, "Radical Doubt and the Liberation of Women"; Jacqueline Broad, "Astell, Cartesian Ethics, and the Critique of Custom", in Mary Astell: Reason, Gender, Faith, eds. William Kolbrener, Michal Michelson (Aldershot: Ashgate, 2007); Jacqueline Broad, The Philosophy of Mary Astell: An Early Modern Theory of Virtue (Oxford: Oxford University Press, 2015). 
for learning we get, and thus the kinds of opportunity for our own enlightenment and salvation, all depend on the context in which our embodied selves live. Astell writes that "Ignorance and a narrow Education, lay the Foundation of Vice, and Imitation and Custom rear it up" (SP I 67). Custom, in particular, is at fault for women's disadvantageous position, it is "that Tyrant Custom, which is the grand motive to all those irrational choices which we daily see made in the World, so very contrary to our present interest and pleasure, as well as to our Future" (SP I 67-68). ${ }^{5}$ This suggests, then, that while our mind might not be gendered, our embodied self is, and the social context in which this self is enculturated impacts on the way in which it develops, and that therefore our experience of the world is shaped by this context as well.

The distinction between the mind and the embodied self that I point to in Astell's writing is the same as that drawn out of Descartes' thought by Deborah Brown between the "minimal" and "maximal" selves. ${ }^{6}$ By drawing on the Sixth Meditation, Brown shows that Descartes uses these two concepts to different ends. The minimal self is the mind understood discretely from the body; this is the sense in which Descartes explains the self in the Sixth Meditation when he writes that "nothing else belongs to my nature or essence except that I am a thinking thing" (CSM II 54, AT VII 78). The maximal self is the composite of mind and body; this is the sense in which Descartes understands the self when he writes later in the same text that he is certain that his body "or rather [his] whole self, insofar as [he is] a combination of mind and body, can be affected by various ... bodies which surround it" (CSM II 56, AT VII 81). Astell likewise maintains this distinction - the minimal self for her is the ungendered mind on the basis of which she argues that men and women have equal capacities for judgment and virtue, while the maximal self is the embodied self, that is, the mind in a substantial union with a body

5 A number of scholars have considered Astell's critique of custom and its role in the subjugation of women in detail. See for instance, Broad, "Astell, Cartesian Ethics, and the Critique of Custom"; Karen Detlefsen, "Custom, Freedom, and Equality: Mary Astell on Marriage and Women's Education”, in Feminist Interpretations of Mary Astell, eds. Penny A. Weiss, Alice Sowaal (University Park: The Pennsylvania State University Press, 2016); Allauren Samantha Forbes, "Mary Astell on Bad Custom and Epistemic Injustice", Hypatia 34, 4 (2019): 777-801.

6 Deborah Brown, "The Sixth Meditation: Descartes and the Embodied Self", in The Cambridge Companion to Descartes' Meditations, ed. David Cunning (Cambridge: Cambridge University Press, 2014), 244-246. 
which is gendered, which forms the basis of her arguments that it is custom and prejudice that hold women back in society.

Some scholars have already noted the Cartesian roots of Astell's account of human nature. For instance, Karen Detlefsen observes, "Astell's equality feminism starts from a commitment to a Cartesian ontology of the human, specifically his dualism of soul and body according to which the thinking soul is the mark of the divine within each of us and is our human essence". At the same time, the literature focuses only on the Cartesian minimal self being the root of Astell's view. Detlefsen goes on, in the same passage, to add that "While the soul may be embodied during our time on earth, it will eventually be free from the body after death" (SP I 52-53). ${ }^{8}$ Since sex is attached to bodies and not to souls, women's human essence is identical with - and thus equal to - that of men". While this reading is undoubtedly correct in identifying Astell's view with the Cartesian ontology of the human and seeing the root of her argument for equality in it, at the same time, this reading only tells half of the story. After all, Astell writes that "Humane Nature consists in the Union of a Rational Soul with a Mortal Body, that the Body very often Clogs the Mind in its noblest Operations, especially when indulg'" (SP II 210). This suggests that while our mind is bonded to the body, the operations of the body have a thorough impact on it. Her critique of society and women's unequal role in it also goes beyond the diagnosis of the problem and seeks a solution, which is the eponymous Proposal.

Astell makes it clear that insofar as we are human beings, we must think of ourselves in the maximal sense as embodied beings, that is, as amalgamations of mind and body. In the second Proposal she writes that "if we disregard the Body wholly, we pretend to live like Angels whilst we are but mortals; and

\footnotetext{
7 Karen Detlefsen, "Cartesianism and Its Feminist Promise and Limits: The Case of Mary Astell", in Descartes and Cartesianism: Essays in Honours of Desmond Clarke, eds. Stephen Gaukroger, Catherine Wilson (Oxford: Oxford University Press, 2017), 197.

${ }^{8}$ Despite Astell's clear statements regarding human beings' embodied nature, and her reliance on the distinction between the embodied self and the disembodied mind, which I discuss in this paper, some scholars have argued that Astell does not have much regard for the body and its role in living a good life, see for instance Cynthia Bryson, "Mary Astell: Defender of the Disembodied Mind", Hypatia: A Journal of Feminist Philosophy 13, 4 (1998): 40-62; Corrine Harol, "Mary Astell's Law of the Heart", in Mary Astell: Reason, Gender, Faith, eds. William Kolbrener, Michal Michelson (Aldershot: Ashgate, 2007).
} 
if we prefer or equal it to the Mind, we degenerate into brutes" (SP II 211). It might well be the case that our immaterial minds are not gendered - but we nonetheless cannot think of our own nature as disembodied; equally, though the body has an impact on the mind, we cannot forget that the mind is ultimately in command of the body. The roles the two substances play in our embodied selves reflect this. For Astell, "the Active powers of the Soul, her Will and Inclinations are at her own dispose, her Passive are not, she can't avoid feeling Pain or other sensible Impressions so long as she's united to a Body, and that Body is dispos'd to convey these Impressions" (SP II 213-214). The soul, as non-extended but rational, is capable of acting, while the body, extended though non-rational, can merely passively transmit sensations. ${ }^{9}$

The influence on the body, and in particular, the gendered differences that this imposes onto the development of the mind, can be seen most clearly from the vices which Astell diagnoses in women. ${ }^{10}$ She writes that it is no wonder women appear to be inferior, if they are "nurs'd up in Ignorance and Vanity, are taught to be Proud and Petulent, Delicate and Fantastick, Humorous and Inconstant" (SP I 61). Such an upbringing, Astell continues, makes it obvious why such vices appear in adulthood (SP I 61). She points to ignorance as the cause of these vices and, importantly for my purpose here, suggests that these vices are "nothing else but Generosity degenerated and corrupted" (SP I 62). Astell understands generosity in the Cartesian sense, that is, as "legitimate self-esteem". ${ }^{11}$ Generosity, for Descartes, is also a firm

9 While it is outside of the scope of this paper, there is a lively debate about what exactly Astell thought was the nature of the connection between the mind and body, in particular with regard to sensation. See for instance, Derek E. Taylor, "Mary Astell's Ironic Assault on John Locke's Theory of Thinking Matter", Journal of the History of Ideas 62, 3 (2001): 505-522; Kathleen M. Squadrito, "Mary Astell's Critique of Locke's View of Thinking Matter". Journal of the History of Philosophy 25, 3 (1987): 433-439; Kathleen M. Squadrito, "Mary Astell”, in A History of Women Philosophers, 1600-1900, ed. Mary Ellen Waithe (Dordrecht: Springer, 1991); Eileen O'Neill, "Mary Astell on the Causation of Sensation", in Mary Astell: Reason, Gender, Faith, eds. William Kolbrener, Michal Michelson (Aldershot and Burlington: Ashgate, 2007).

${ }^{10}$ For a more in-depth discussion of the question of women's vice in Astell see, Sowaal, "Mary Astell and the Development of Vice: Pride, Courtship, and the Woman's Human Nature Question"; Alice Sowaal, "Mary Astell on Liberty", in Women and Liberty, 1600-1800: Philosophical Essays, eds. Jacqueline Broad, Karen Detlefsen (Oxford: Oxford University Press, 2017).

${ }_{11}$ Broad, The Philosophy of Mary Astell: An Early Modern Theory of Virtue, 96. 
awareness of our free will and a resolution to use it well, in accordance with our best judgements (CSM I 384, AT XI 446). This is to say then, that for Astell vice consists in degenerated self-esteem and not acting on one's best judgements. After all, how can women exercise their judgements if they are prevented from an education that would allow them to develop their critical abilities? It is therefore unsurprising that Astell writes that women's supposed intellectual "Incapacity, if there be any, is acquired not natural" (SP I 59), and it is ingrained primarily by a lack of education (SP I 60). The prejudice against women, however, though manifesting as preventing them from acquiring an education, really stems from the different ways in which men's and women's bodies are treated. As Astell shows, the mind is not gendered, which is to say, there are no innate differences between the minds of men and women - and the difference in treatment in society results therefore from the differences in their bodies. ${ }^{12}$ This is confirmed when Astell suggests that "[w]ere the Men as much neglected, and as little care taken to cultivate and improve them, perhaps they wou'd be so far from surpassing those whom they now dispise, that they themselves wou'd sink into the greatest stupidity and brutality" (SP I 57).

Astell's account of the inequality between men and women is grounded on crucial parts of the Cartesian theory of the passions. Vice is an ill-tempered passion and emerges from the way in which women's bodies are enculturated and from the lack of education women suffer that could alleviate it. To see this clearly, it is now worth looking at how Astell understands the passions, and how this understanding shapes her views in the Proposals.

12 This is not to say that Astell did not think that there are no differences in rational capacity between people. For instance, in the second Proposal, she writes that she sees "no reason why there may not be as great a variety in Minds as there is in faces" (SP II 153, she repeats this in CR 201). The point however is that the differences in rational capacity are not gendered. On this, see Detlefsen, "Custom, Freedom, and Equality: Mary Astell on Marriage and Women's Education", 76, who develops this idea further and contrasts it with Descartes, whom she takes to hold the position that rational capacities are equal between minds. 


\section{Passion, Vice and Virtue}

Astell indicates two related sources for her understanding of the passions, Descartes and Henry More. In the second Proposal, she writes that she cannot add anything to what "they have so well Discours'd" (SP II 218). ${ }^{13}$ Given More's debt to Descartes' theory, and that in her Christian Religion, as Professed by a Daughter of the Church of England (1705), Astell likewise refers to Descartes' taxonomy of the passions (CR 196-199), there is good reason to say she is employing and building on the Cartesian view. ${ }^{14}$ Astell gives a clear statement of her understanding of the passions in the fourth chapter of the second Proposal. Here, she tells us that they are those perceptions in the soul that are caused by commotions of the blood and animal spirits (SP II 214). We are passive with regard to them - a person is "no more able to prevent these first Impressions than she is to stop the Circulation of the Bloud, or to hinder Digestion" (SP II 214). Our options concerning the passions are to let them run their course, to shift them to another object, or to try to modify them in some way; the latter of these options being what Astell defines as a virtue, which according to her, consists in "governing Animal Impressions, in directing our Passions to such Objects, and keeping 'em at such a pitch, as right Reasons requires" (SP II 214)..$^{15}$

Like Descartes, Astell suggests that the passions can be beneficial and pleasant. She considers them to be "natural and unavoidable", and their use to be motivating us to act in various ways, according to "the Determination of the Mind" (SP II 214). ${ }^{16}$ Like Descartes, Astell also thinks this is part of

13 For a direct comparison between Astell and More, see Broad, "Astell, Cartesian Ethics, and the Critique of Custom".

${ }^{14}$ In her annotations to this text, Jacqueline Broad points to the fact that Astell supplements Descartes' taxonomy with More's, see CR pp. 196-7, fn.45.

15 In the Christian Religion, Astell writes that "reason conducted by grace" must command the passions if we are to live a "virtuous religious life" (CR 245); Broad traces this formulation of the definition of virtue to Charles Hickman's Fourteen Sermons Preached, at St James's Church in Westminster (CR 245 fn.248).

${ }_{16}$ This suggests Astell's understanding of the passions is that they are motivational and not representational. A similar reading of the Cartesian view is defended for instance by Sean Greenberg ("Descartes on the Passions: Function, Representation and Motivation", 
the problem with the passions - if we are not careful, they will suggest the wrong course of action. Astellian virtue consists in training the passions to remain within limits set by reason. This, she writes, "is what we can and ought to do, and if we do not perform it, we act rather like the Slaves of Sense than Creatures endued with Reason; but if we do, we can hardly receive any Injury from the Passions" (SP II 214). Finally, like Descartes, Astell writes that the passions depend in many ways on the make-up of the body. She tells us that the passions depend on "the Constitution of the Body, Age, Education, and way of Living", and that, therefore, the same external object affects different people differently (SP II 216).

The Cartesian passion of generosity is the foundation of Astell's understanding of vice and virtue. Descartes defined it as a species of wonder (CSM I 350, AT XI 373), which can maximise our self-esteem, and which consists of knowing that we have free will and of having the resolution to use our will in accordance with our best judgements (CSM I 384, AT XI 445-6). For him, generosity is the focal point of our moral practice - by cultivating generosity we are able to bring all of the other passions in line, which is why it is the "remedy against all the disorders of the passions" (CSM I 385, AT XI 447). More's definition of generosity in his Account of Virtue is similar. He writes that in generosity, "a Man exercise his own freedom and liberty of Thinking in the best manner he can; that he rest contented hereto; and as to Fortune, and the World's Opinion, to look on them as things of indifferency; yet still to regard all Men with Civility, and to suppose them what they ought to be, till the contrary be made manifest". ${ }^{17}$ More and Descartes both agree that generosity consists in the firm knowledge that nothing belongs to us but the free exercise of our will.

Astell's understanding of generosity follows the Cartesian path. She included a short discourse on generosity in a 1714 letter to her friend, Ann Coventry. According to Jacqueline Broad, ${ }^{18}$ this is doubtlessly John Som-

Noûs 4 (2007): 714-734) and Shoshana Brassfield ("Never Let the Passions be Your Guide: Descartes and the Role of the Passions", British Journal of the History of Philosophy 20, 3 (2012): 459-477).

${ }^{17}$ Henry More, An Account of Virtue: or, Dr. Henry More's Abridgment of Morals, transl. Edward Southwell (London: Benjamin Tooke, 1690), 143.

18 Broad, The Philosophy of Mary Astell: An Early Modern Theory of Virtue, 105. 
ers' A Discourse concerning Generosity (1693), a Cartesian text examining generosity in detail. In the letter, Astell laments that it is the "common lot of all those Generous Persons who have gone before us" to be "extinguish'd" by the envy and ill-nature of others. According to her, the generous, that is, "all who make a Right use of their Liberty, endeavouring to do always what is Best", have no choice but to submit to this treatment, or even "[be] Gloried in" the circumstances they face. ${ }^{19}$ The wording Astell uses to describe the generous person fits Descartes' own description. In the second Proposal, she elaborates to say that "the Author of our nature" has given us the tools sufficient to face any of the difficulties of this life, "One of these is Generosity, which (so long as we keep it from degenerating into Pride) is of admirable advantage to us in this matter" (SP II 141). Generosity, along with courage, is also necessary to "throw off Sloth and to Conquer the Prejudices of Education, Authority and Custom" (SP II 140). This is to say generosity is at the centre of Astell's programme of moral development.

Generosity is also central to Astell for the influence it has on a person's self-esteem. Kathleen Ahearn writes that Astell's task of assisting women in overcoming their "groveling Spirit" (SP II 232) requires the kind of proper management of the passions to achieve virtue and happiness that Descartes' theory of the passions is made for. ${ }^{20}$ Specifically, Descartes holds that generosity "causes a person's self-esteem to be as great as it may legitimately be" (CSM I 384, AT XII 445). Astell recognises this when she describes the "feminine vices" as "nothing else but Generosity degenerated and corrupted" (SP I 62). This degradation of women is caused by being in a society where the custom is to mock and degrade them. ${ }^{21}$ In other words, society, by the way it treats women in their embodiment, causes them to degenerate into a cycle of vice, from which they cannot easily escape. This being the case, it is not merely women's generosity that is affected by custom, but all of their passions.

19 Ruth Perry, The Celebrated Mary Astell (Chicago: The University of Chicago Press, 1986), 370-371.

${ }^{20}$ Kathleen A. Ahearn, "Mary Astell's Account of Feminine Self-Esteem", in Feminist Interpretations of Mary Astell, eds. Alice Sowaal, Penny A. Weiss (University Park: The Pennsylvania State University Press, 2016), 36.

${ }^{21}$ Alice Sowaal, "Mary Astell's Serious Proposal: Mind, Method, and Custom”, Philosophy Compass 2, 2 (2007): 232. 
The focus on the role of self-esteem and generosity in the production of virtue and vice in women is telling of the importance of understanding the distinction between the minimal and maximal self in Astell's thought. The minimal self is the foundation of her critique: fundamentally, women's minds taken on their own, as distinct from their bodies, are indistinguishable from those of men. Therefore, men and women ought to be treated equally. This being the case, Astell anticipates an objection: if men and women have equal minds, why do women appear as inferior? Astell's response is cashed out by showing the impact embodiment has on the mind. The passions occur in the mind as a result of its close connection to the body. If vice is the product of ill-tempered passions, then reasonably one can conclude that the actual cause of women's seeming inferiority is the way how their embodied selves are enculturated and socialised. This is to say, Astell's argument is that women as embodied and socially situated agents suffer from unique disadvantages that are the product of their bodies being treated differently to men's bodies. By being deprived of the ability to gain an education and by being enculturated to value things such as beauty or money (SP I 62), women are made to become inferior to men.

In making these arguments, Astell builds significantly on Descartes' theory of the passions. Both authors agree that the passions affect people differently at different ages (CSM I 374, AT XI 426, SP II 216) and that the passions can differ in people depending on their life experience (e.g. CSM I 376, AT XI 429, SP II 216). However, what is missing in Descartes' theory of the passions is an understanding of how men and women differ in their experience, and thus of the role the gendered context of their embodiment has on developing their passions. The closest he comes to understanding the influence of social context on the passions is in a passing remark to Elisabeth in a letter dated 18 May 1645, where commenting on a persistent "low-grade fever", he writes that "the stubbornness of fortune in persecuting your house continually gives you matters for annoyance which are so public and so terrible that it is necessary neither to conjecture very much nor to be particularly experienced in social matters to judge that the principal cause of your indisposition consists in these" (C 86, AT IV 200). This is to say, Descartes recognises that Elisabeth's social context has had a pronounced effect on her passions and bodily health. However, this is not yet an acknowledgement that the kinds of 
passion we experience in response to everyday events are shaped by our social context. Astell makes this point much more explicitly by linking custom and social prejudice directly to the kinds of passion women develop. Vice, which Astell defines in terms of corrupted passions, is caused, in her view, by the social conditions women are brought up under and have to live in. These conditions affect the mind via its close connection to the body; that is, they influence women's maximal selves.

Our social context also matters in another way for developing our passions and virtue. Namely, Astell considers friendship to be a necessary part of tempering our passions. In the first Proposal, she writes that friendship is worth more than all other pleasures (SP I 75), that it is "without doubt the best Instructor to teach us our duty to our Neighbour" and that it "has a special force to dilate our hearts, to deliver them from that vicious selfishness and the rest of those sordid Passions which express a narrow, illiberal temper" (SP I 99). She proposes that friendship can grant women "those perfections [their] feigned lovers pretended [they] had, and kept [them] from obtaining" (SP I 74). Given the benefits of friendship and the key role it plays in women's moral development, it is unsurprising that Astell suggests that in the sanctuary she proposes, women "shall have the opportunity of contracting the purest and noblest Friendship" (SP I 98). Friends can help steer us toward the right path, but more importantly, the passages quoted here show that true friends establish a social context in which we are no longer subject to the prejudices and customs which are harmful to us. This is to say, friendship provides the proper social context for our moral development and allows the embodied self to be free of those influences which degenerate our passions into vice. ${ }^{22}$

22 A number of contemporary scholars have considered Astell's view of friendship more closely, see Jacqueline Broad, "Mary Astell on Virtuous Friendship", Parergon 26, 2 (2009): 65-86; Nancy Kendrick, "Mary Astell's Theory of Spiritual Friendship", British Journal for the History of Philosophy 26, 1 (2017): 46-65; William Kolbrener, "Astell's 'Design of Friendship' in Letters and A Serious Proposal, Part I", in Mary Astell: Reason, Gender, Faith, eds. William Kolbrener, Michal Michelson (Aldershot: Ashgate, 2007). 


\section{Overcoming Vice}

Having considered the roots of Astell's critique of women's position in society, and her view of the effect of this position on the development of women's moral character, I now turn to analysing the positive solution she offers. Astell emphasises in many places in her work that she thinks philosophy and education ought to be practical. She tells her readers that "it is to little purpose to Think well and speak well, unless we Live well" (SP II 199) and that "Truths merely Speculative and which have no influence upon Practice, which neither contribute to the good of Soul or Body are but idle Amusements, an impertinent and criminal wast of Time" (SP II 143). What then should we take to be the practical goal of philosophy?

Jacqueline Broad understands it to be emancipation, which, on her reading of Astell, "consists in liberating the will from the 'manacle' of custom (SP II 139); freedom is freedom of the will rather than freedom from bodily constraint". ${ }^{23}$ This is to say, Broad understands the target to be an intellectual liberation for women from the oppressive shackles imposed upon them by society via custom and lack of educational opportunities. Astell gives us good reasons to think that, for her, intellectual emancipation is inseparable from reforming the way in which women qua embodied minds are treated and enculturated. As I have shown above, Astell characterises the vices which emerge from women's position in society as degenerated passions. The liberation of women's minds, therefore, requires the liberation of women's bodies from unequal treatment in society. Astell's proposal stems from this basic premise. Astell calls for the establishment of a women's only school, where women can be educated and therefore cultivate better judgements. If Astell's point were to liberate only women's minds, then it would be unclear why she would not advocate for women's equal access to education within existing institutions. Astell's goal, however, is broader than that: it is to liberate women's minds qua embodied minds. As such, women would not benefit (at least, not

${ }^{23}$ Jacqueline Broad, "Mary Astell and the Virtues", in Feminist Interpretations of Mary Astell, eds. Alice Sowaal, Penny A. Weiss (University Park: The Pennsylvania State University Press, 2016), 22. 
at first) from equal access to educational facilities with men, since then, their bodies would still be treated as women's bodies - that is, they would face the same ingrained prejudice and custom that prevents them from being able to acquire an education in the first place.

The educational facility Astell wants to establish serves two general goals, "the service of GOD and improvement of [women's] own Minds" (SP I 73). To fulfil the first of these goals, Astell thinks we need to cultivate the passion of love with God as its object. In this, Astell makes her most significant departure from Descartes' theory of the passions by shifting the focus away from generosity as the key to controlling the passions. ${ }^{24}$ She defines love similarly to Descartes, as "a motion of the Soul to joyn it self to that which appears to be grateful to it" (SP II 219, compare CSM I 356, AT XI 387), writes that it "seems to be the predominant passion in every one" (SP II 219), and suggests that love is "at the bottom of all the Passions" and indeed that "one wou'd think they're nothing else but different Modifications of it" (SP II 219). Given this, Astell argues that if we direct our love appropriately, the rest of our passions will follow. She writes in the second Proposal that "If therefore our Love be Right, the rest of our Passions will of course be so" and that it is "GOD who is the only proper and adequate Object of our Love" (SP II 219). The service of God thus has two benefits: first, it helps us regulate our behaviour by providing a measure by shifting the goals of our actions towards seeking divine approbation (SP II 220), second, it helps us regulate our passions, since ordering our passions right, by cultivating the love of God above all else, leads the rest of the passions to follow (SM II 219). By the second goal, improving women's minds, Astell understands helping women overcome ignorance,

${ }^{24}$ In this, Astell is doubtlessly influenced by Malebranche and Norris, who similarly shift the focus of the Cartesian theory of the passions. This is also not the only departure she makes from the Cartesian view, for instance, Broad argues that in the Christian Religion Astell talks of completely eliminating certain passions, such as pride, anger, hatred, and overwhelming sorrow, as the gospel commands us to "'put off all these' of what kind so ever, assuring us that such sinful 'flesh and blood can't inherit the kingdom of God"' (CR 252). Broad argues that this suggests that for Astell there are some passions that are not useful and ought to be discarded (Broad, The Philosophy of Mary Astell: An Early Modern Theory of Virtue, 89). This ambivalence about certain passions is shared by Astell and Malebranche. Broad sees in Astell echoes of the Malebranchean view that the body tyrannizes the mind and tears it away from God (Broad, The Philosophy of Mary Astell: An Early Modern Theory of Virtue, 89). 
which she understands as the "cause of most Feminine Vices" (SP I 62) and as originating "from a want of understanding to compare and judge of things, to chuse a right End, to proportion the Means to the End, and to rate ev'ry thing according to its proper value" (SP I 64). The two goals for the women's retreat are not mutually exclusive - cultivating the passions goes hand in hand with cultivating our judgements. Ultimately, Astell thinks both of these things are necessary before women can be considered equal participants in society, she writes, “... it is fit we Retire a little, to furnish our Understandings with useful Principles, to set our Inclinations right, and to manage our Passions, and when this is well done, but not till then, we may safely venture out" (SP II 232). That Astell thinks the goals she has in mind for women's education can only be best achieved in a women's retreat shows that she understands that the social context under which our embodied self develops matters. The proposal, then, is to establish a space where the social context is not harmful, but rather is beneficial, to women's development.

As far as the practice of refining women's judgements is concerned, prima facie Astell adopts the same solution as Descartes, Malebranche and Norris. That is, like them, Astell argues that cultivating and sharpening our judgements is the solution to the disarray of the passions, and it is by doing so that we can come to acquire generosity (or rather, in Astell's case, save it from being degenerated). More specifically, as Broad shows, Astell relies on the developmental program proposed by John Norris in his Reflections on the Conduct of Human Life (1697), which consists of three parts: developing our judgements (using his rules for thinking), developing purity of "Heart and Life", and prayer. ${ }^{25}$ Astell refers her readers to Norris' "course of study" in the first Proposal (SP I 78) and adopts the recommendation of the necessity of purity for moral development in the second (SP II 131).

Astell outlines the method she prescribes for cultivating judgements as a set of six rules (SP II 176-178), deviating slightly from Norris:

25 Broad, The Philosophy of Mary Astell: An Early Modern Theory of Virtue, 33. See also, Norris ("Reflections on the Conduct of Human Life: With Reference to the Study of Learning and Knowledge", in Treatuses Upon Several Subjects (London: S. Manship, 1697), 75-81) for his own description of the method. 
1. Acquaint our selves thoroughly with the State of the Question, have a Distinct Notion of our Subject whatever it be, and of the Terms we make use of, knowing precisely what it is we drive at.

2. Cut off all needless Ideas and whatever has not a necessary Connexion to the matter under Consideration.

3. To conduct our Thoughts by Order, beginning with the most Simple and Easie Objects, and ascending as by Degrees to the Knowledge of the more Compos'd.

4. Not to leave any part of our Subject unexamin'd.

5. Always keep our Subject Directly in our Eye, and Closely pursuye it thro all, our Progress.

6. To judge no further than we Perceive, and not to take any thing for Truth, which we do not evidently Know to be so.

The first three of these rules are the same as those given by Malebranche in his Search After Truth, ${ }^{26}$ and which were later summarised by Norris. ${ }^{27}$ Astell's rules also harken to those given by Pierre Nicole and Antoine Arnauld in their Logic, or the Art of Thinking, a work Astell cites several times throughout her Proposal. ${ }^{28}$ Ultimately, all of these thinkers base their rules on those Descartes set out in part 2 of his Discourse on the Method (CSM I 120, AT VI 18-19). ${ }^{29}$ The most important thing that Astell's rules share with the other Cartesians, and Descartes himself is their purpose - namely, combatting ignorance in the service of moderating the passions and cultivating virtue.

Astell writes that ignorance leads to most vices (SP I 62) and that it is the "Foundation of Vice" that is backed up by custom and prejudice (SP I 67). Overcoming ignorance, however, is not as simple as perfecting one's

26 Nicholas Malebranche, The Search After Truth and Elucidations, eds. Thomas M. Lennon, Paul J. Olscamp (Cambridge: Cambridge University Press, 1997), 438.

27 Norris, "Reflections on the Conduct of Human Life: With Reference to the Study of Learning and Knowledge", 205-208.

${ }^{28}$ For Arnauld and Nicole (Logic, or the Art of Thinking, ed. and transl. Jill V. Buroker (Cambridge: Cambridge University Press, 1996)) discussion of Descartes' rules, see p. 238 of the Logic, and for their discussion of their own rules, see p. 259.

29 For a closer comparison of the similarities and differences between the sets of rules articulated by Descartes, Malebranche, Norris, and Arnauld and Nicole, see Sowaal, "Mary Astell's Serious Proposal: Mind, Method, and Custom": 227-243; Broad, The Philosophy of Mary Astell: An Early Modern Theory of Virtue, 31-33. 
understanding. Astell writes that knowledge must be paired with the purity of character. She writes that the woman "who desires a clear Head must have a pure Heart; and she who has the first in any Measure will never allow herself to be deficient in the other" (SP II 127). The reason for this is that "the Corruption of the Heart" contributes more to our ignorance than the "Clearness of our Light" does to the regularity of our affections (SP II 130). Norris ${ }^{30}$ describes purity as consisting in chastity and temperance and suggests that its purpose is to help "clarify the medium" - that is the body - which is clouded by the passions, particularly by the desire of terrestrial things. In sum, Astell highlights two opposites - on the one hand ignorance, on the other the regularity of our affections. In other words - the ultimate purpose of education, if it is to lead to virtue (i.e. away from ignorance), is the regulation of our passions. Achieving this goal requires not only good judgements (i.e. knowledge) but also the purity of heart. As far as training our judgements goes, as we have seen, Astell employs the rules for judgement drawn from Malebranche and Norris, Nicole and Arnauld, but ultimately rooted in Descartes' epistemology. By drawing on Norris' notion of purity, Astell highlights the inadequacy of training our judgements as separate from other aspects of our lives.

Given the genderless nature of the disembodied mind, and thus the equal potential for moral development that men's and women's minds hold, it is worth considering why exactly the above method could not be attained in a co-educational facility. As Penny Weiss shows, Astell's goal is not here to replicate the conditions men enjoy in their education, as if they were faultless. ${ }^{31}$ Rather, Astell's analysis of the socially conditioned nature of moral development leads her to recognise the inequality in power men and women face in society. In an educational context, this would mean that women qua embodied minds would still be treated according to the custom which treats their female bodies poorly. Astell notes that the conditioning to custom happens from childhood (SP I 60). Therefore, a co-educational facility

${ }^{30}$ Norris, "Reflections on the Conduct of Human Life: With Reference to the Study of Learning and Knowledge", 211.

31 Penny A. Weiss, "From the Throne to Every Private Family: Mary Astell as Analyst of Power", in Feminist Interpretations of Mary Astell, eds. Alice Sowaal, Penny A. Weiss (University Park: The Pennsylvania State University Press, 2017). 
would perpetuate the inequality between men and women instead of providing women with the space to develop as virtuous moral agents in their own right. $^{32}$

\section{Conclusion}

This paper shows that Astell's philosophy, and in particular, the key parts of her feminist philosophical program take Cartesian philosophy as their starting point. She follows Descartes' ontology of the human to show that the mind has no gender. However, our bodies are gendered, which means that so is our embodied self. From here, Astell is able to show that those things that are vices for women - especially those related to the passions, come from the way in which women's bodies are socialised, this is to say, our passions are socially determined because in society men's and women's bodies are treated differently. This is a significant development on the Cartesian theory of the self, which brings out and addresses a shortcoming in Descartes' theory namely, the lack of attention paid to the fact that social context supervenes on the development of the self. In addressing this, I show Astell does not reject the Cartesian view but elaborates on it by showing that it is custom and prejudice which lead to women's position in society.

The solution Astell proposes to address this societal inequality likewise relies on the Cartesian theory of the passions. Her innovation here is, again, to build a feminist social theory on top of the Cartesian view of the passions. In her recognition that social context shapes the self and the passions, she proposes an educational refuge for women. It must be for women only, since only by removing the social context in which women are customarily neglected (i.e. treated not as embodied minds, but as women) can they overcome the limitations imposed by bad custom. The refuge would provide women with a space to train their passions and refine their judgements so

32 See also Forbes, "Mary Astell on Bad Custom and Epistemic Injustice", for an analysis of how structural inequality and custom manifest as an epistemic injustice in preventing women from being able to fully exercise their epistemic powers. 
that they might be set on a path to developing virtue. In other words, the refuge would apply to the Cartesian moral program as women's education.

Astell's multifaceted philosophical work thus shows two things. First, a Cartesian diagnosis and solution to the problem of women's unequal place in society, and second, the political potential held by Cartesian philosophy, and especially the theory of the passions.

\section{References}

Adam Charles, Tannery Paul (eds.). 1996. Oeuvres de Descartes (11 vols.). Paris: J. Vrin.

Ahearn Kathleen A. 2016. "Mary Astell's Account of Feminine Self-Esteem”. In Feminist Interpretations of Mary Astell, eds. Alice Sowaal, Penny A. Weiss. University Park: The Pennsylvania State University Press.

Arnauld Antoine, Nicole Pierre. 1996. Logic, or the Art of Thinking, transl. and ed. Jill V. Buroker. Cambridge: Cambridge University Press.

Astell Mary. 2013. The Christian Religion, as Professed by a Daughter of the Church of England, ed. Jacqueline Broad. Toronto: Center for Reformation and Renaissance Studies.

Astell Mary. 2002. A Serious Proposal to the Ladies. parts I and II, ed. P. Springborg. Ontario: Broadview Literary Texts.

Atherton Margaret. 1993. Cartesian Reason and Gendered Reason. In A Mind of One's Own: Feminist Essays on Reason and Objectivity, eds. Louise M. Antony, Charlotte Witt, 472-493. Boulder and Oxford: Westview Press.

Brassfield Shoshana. 2012. Never Let the Passions be Your Guide: Descartes and the Role of the Passions. British Journal of the History of Philosophy 20, 3: 459-477.

Broad Jacqueline. 2002. Women Philosophers of the Seventeenth Century. Cambridge: Cambridge University Press.

Broad Jacqueline. 2007. "Astell, Cartesian Ethics, and the Critique of Custom". In Mary Astell: Reason, Gender, Faith, eds. William Kolbrener, Michal Michelson, 165-179. Aldershot: Ashgate.

Broad Jacqueline. 2009. "Mary Astell on Virtuous Friendship". Parergon 26, 2: 65-86. Broad Jacqueline. 2015. The Philosophy of Mary Astell: An Early Modern Theory of Virtue. Oxford: Oxford University Press.

Broad Jacqueline. 2016. "Mary Astell and the Virtues". In Feminist Interpretations of Mary Astell, eds. Alice Sowaal, Penny A. Weiss. University Park: The Pennsylvania State University Press. 
Brown Deborah. 2014. "The Sixth Meditation: Descartes and the Embodied Self". In The Cambridge Companion to Descartes' Meditations, ed. David Cunning, 240-257. Cambridge: Cambridge University Press.

Bryson Cynthia. 1998. "Mary Astell: Defender of the Disembodied Mind". Hypatia: A Journal of Feminist Philosophy 13, 4: 40-62.

Descartes René. 1641/1984. "The Meditations on First Philosophy”. In The Philosophical Writings of Descartes. Vol. II, eds. John Cottingham, Robert Stoothoff, Dugald Murdoch. Cambridge: Cambridge University Press.

Descartes René. 1649/1985. "The Passions of the Soul", trans. Robert Stoothoff. In The Philosophical Writings of Descartes. Vol. 1, eds. John Cottingham, Robert Stoothoff, Dugald Murdoch. Cambridge: Cambridge University Press.

Detlefsen Karen. 2016. "Custom, Freedom, and Equality: Mary Astell on Marriage and Women's Education". In Feminist Interpretations of Mary Astell, eds. Penny A. Weiss, Alice Sowaal, 74-92. University Park: The Pennsylvania State University Press.

Detlefsen Karen. 2017. "Cartesianism and Its Feminist Promise and Limits: The Case of Mary Astell". In Descartes and Cartesianism: Essays in Honours of Desmond Clarke, eds. Stephen Gaukroger, Catherine Wilson, 191-206. Oxford: Oxford University Press.

Forbes Allauren Samantha. 2019. "Mary Astell on Bad Custom and Epistemic Injustice". Hypatia 34, 4: 777-801.

Greenberg Sean. 2007. "Descartes on the Passions: Function, Representation and Motivation". Noûs 4: 714-734.

Harol Corrine. 2007. "Mary Astell's Law of the Heart". In Mary Astell: Reason, Gender, Faith, eds. William Kolbrener, Michal Michelson, 87-97. Aldershot: Ashgate.

Kendrick Nancy. 2017. "Mary Astell's Theory of Spiritual Friendship". British Journal for the History of Philosophy 26, 1: 46-65.

Kinnaird Joan K. 1976. "Mary Astell and the Conservative Contribution to English Feminism". Journal of British Studies 19, 1: 61-62.

Kolbrener William. 2007. "Astell's 'Design of Friendship' in Letters and A Serious Proposal, Part I". In Mary Astell: Reason, Gender, Faith, eds. William Kolbrener, Michal Michelson, 49-64. Aldershot: Ashgate.

Lloyd Genevieve. 1984. The Man of Reason: "Male" and "Female" in Western Philosophy. Minneapolis: University of Minnesota Press.

Malebranche Nicholas. 1997. The Search After Truth and Elucidations, eds. Thomas M. Lennon, Paul J. Olscamp. Cambridge: Cambridge University Press.

More Henry. 1690. An Account of Virtue: or, Dr. Henry More's Abridgment of Morals, trans. Edward Southwell. London: Benjamin Tooke.

Negri Antonio. 2007. Political Descartes: Reason, Ideology and the Bourgeois Project, trans. Alberto Toscano, Matteo Mandarini. London: Verso. 
Norris John. 1697. "Reflections on the Conduct of Human Life: With Reference to the Study of Learning and Knowledge". In Treatuses Upon Several Subjects. London: S. Manship.

O’Neill Eileen. 1999. "Women Cartesians, 'Feminine Philosophy', and Historical Exclusion". In Feminist Interpretations of René Descartes, ed. Susan Bordo, 232-257. University Park: The Pennsylvania State University Press.

O'Neill Eileen. 2007. "Mary Astell on the Causation of Sensation". In Mary Astell: Reason, Gender, Faith, eds. William Kolbrener, Michal Michelson, 145-164. Aldershot and Burlington: Ashgate.

Perry Ruth. 1984. "Mary Astell's Response to the Enlightenment". In Women and the Enlightenment, eds. Margaret Hunt, Margaret Jacob, Phyliss Mack, Ruth Perry, 13-40. New York: Institute for Research in History and the Haworth Press.

Perry Ruth. 1985. "Radical Doubt and the Liberation of Women". Eighteenth-Century Studies 18, 4: 472-493.

Perry Ruth. 1986. The Celebrated Mary Astell. Chicago: The University of Chicago Press.

Rogers Katharine M. 1982. Feminism in Eighteenth-Century England. Urbana: University of Illinois Press.

Shapiro Lisa (ed.). 2007. The Correspondence between Princess Elisabeth of Bohemia and René Descartes. Chicago: The University of Chicago Press.

Smith Hilda L. 1982. Reason's Disciples: Seventeenth-Century English Feminists. Chicago: University of Illinois Press.

Smith Hilda L. 1992. "Intellectual Bases for Feminist Analyses: The Seventeenth and Eighteenth Centuries". In Women and Reason, eds. Elizabeth D. Harvey, Kathleen Okruhlik, 19-38. Ann Arbor: University of Michigan Press.

Sowaal Alice. 2007. "Mary Astell's Serious Proposal: Mind, Method, and Custom". Philosophy Compass 2, 2: 227-243.

Sowaal Alice. 2016. "Mary Astell and the Development of Vice: Pride, Courtship, and the Woman's Human Nature Question". In Feminist Interpretations of Mary Astell, eds. Alice Sowaal, Penny A. Weiss. University Park: The Pennsylvania State University Press.

Sowaal Alice. 2017. "Mary Astell on Liberty". In Women and Liberty, 1600-1800: Philosophical Essays, eds. Jacqueline Broad, Karen Detlefsen, 178-194. Oxford: Oxford University Press.

Squadrito Kathleen M. 1987. "Mary Astell's Critique of Locke's View of Thinking Matter". Journal of the History of Philosophy 25, 3: 433-439.

Squadrito Kathleen M. 1991. "Mary Astell". In A History of Women Philosophers, 1600-1900, ed. Mary Ellen Waithe, 87-100. Dordrecht: Springer.

Stuurman Siep. 2004. François Poulain de la Barre and the Invention of Modern Equality. Cambridge: Harvard University Press. 
Taylor E. Derek. 2001. “Mary Astell's Ironic Assault on John Locke’s Theory of Thinking Matter". Journal of the History of Ideas 62, 3: 505-522.

Watson Richard A. 2007. Descartes's Ballet: His Doctrine of the Will and His Political Philosophy. South Bend: St. Augustine's Press.

Weiss Penny A. 2017. "From the Throne to Every Private Family: Mary Astell as Analyst of Power". In Feminist Interpretations of Mary Astell, eds. Alice Sowaal, Penny A. Weiss, 128-152. University Park: The Pennsylvania State University Press.

Welch Marcelle Maistre (ed.). 2002. Three Cartesian Feminist Treatises. Chicago: The University of Chicago Press. 